\title{
Failure to Connect: The Massachusetts Plan for Individual Health Insurance
}

\author{
Elizabeth A. Weeks
}

\section{INTRODUCTION}

In April 2006, Massachusetts established historic precedent by enacting comprehensive health care reform that promises near-universal coverage for the state's residents, including 550,000 previously uninsured. The Massachusetts Plan is a unique combination of employer incentives, individual mandates, government subsidies, managed competition, tax incentives, and expansion of existing state welfare and federally funded programs. The provisions embrace both left-leaning ideals of health care as a right as well as right-leaning preferences for health as an individual responsibility. Existing features of Massachusetts's health care system, including a highly regulated insurance market, small population, relatively low uninsured rate, and generous uncompensated care fund, may have facilitated passage and implementation of the ambitious reform package. Those preconditions present challenges for other states considering both the practicality and desirability of similar reform.

The individual and employer mandates, in particular, are ambitious and controversial. Employers with more than ten employees are required to offer health insurance to employees or pay an annual per-employee penalty. ${ }^{1}$ Individuals who do not have or do not enroll in employer health plans must purchase individual coverage or face state income tax penalties. $^{2}$ The difficulty for individuals and small employers, historically, has been finding affordable health insurance without the bargaining-power and risk-pooling advantages that large employers bring to the table. To correct that market condition, the Massachusetts Plan establishes the Commonwealth Health Insurance Connector (Connector),

\footnotetext{
Associate Professor of Law, University of Kansas School of Law.

1. See infra Part II.A (discussing the employer "pay or play" requirement).

2. See infra Part II.B (discussing the individual mandate).
} 
designed to connect individuals, young adults, and small employers to affordable quality health insurance. ${ }^{3}$

This Article briefly describes the key features of the Massachusetts Health Care Reform Act, focusing particularly on the Connector. It then offers preliminary thoughts on the expected effect of that mechanism for creating quality, affordable health insurance products for individuals. Commentators anticipate that commercial insurers will offer scant coverage and high-premium, high-deductible plans through the Connector, which coverage ultimately may be neither more affordable than current products nor more useful than no coverage at all. ${ }^{4}$ If the Connector fails to facilitate the individual insurance mandate, Massachusetts's promise of universal coverage may begin to unravel. Moreover, the Plan's usefulness as a model for other states proposing or considering similar risk-pooling mechanisms will be greatly diminished.

\section{ELEMENTS OF THE MASSACHUSETTS Plan}

After giving a brief overview of the various pieces of the patchwork Massachusetts Plan in Part II and Massachusetts's history of health care reform in Part III, Part IV takes a closer look at one feature of the Planthe Connector-a quasi-governmental risk-pooling mechanism. The Article describes the expected characteristics of Connector individual health insurance plans and the vulnerabilities that those plans present for individuals and the Plan itself. The first components of the Plan took effect on January 1, 2007..$^{5}$ Massachusetts and other states are anxiously awaiting the results. Meanwhile, other states, most recently California in January 2007, introduced their own versions, with some noteworthy variations. $^{6}$ Massachusetts's experience offers important lessons for states attempting similar programs and begs the question whether there are reasons that the Massachusetts Plan, even if successful there, could be even more difficult to replicate elsewhere.

3. See infra Part Il.D (describing the Connector).

4. See, e.g., John Holahan \& Linda Blumberg, Massachusetts Health Care Reform: A Look at the Issues, 2006 HEALTH AFF.: WEB EXCLUSIVES w432, w439 (noting that plans available through the Connector may "be dominated by plans with high deductibles, other types of high cost-sharing requirements, or benefit limitations").

5. An Act Providing Access to Affordable, Quality, Accountable Health Care, ch. 58, $\S 142$, 2006 Mass. Acts (forthcoming), available at http://www.mass.gov/legis/laws/seslaw06/s1060058. htm [hereinafter Mass. Plan].

6. See infra Part III.C (comparing California's plan with the Massachusetts Plan). 
Governor Mitt Romney signed the Massachusetts Health Care Reform Plan $^{7}$ on April 12, 2006. ${ }^{8}$ The Plan promises, but does not guarantee or directly provide, universal coverage to Massachusetts residents. ${ }^{9}$ The public-private patchwork Plan is distinctly different from universal coverage, which distinction was essential to its passage. ${ }^{10}$ Single-payor, or "socialized" medicine, like the doomed Clinton plan, would likely have been a political non-starter. ${ }^{11}$ Massachusetts's politics featured, on one side of the aisle, a Republican governor, who has since entered the 2008 presidential race, representing the view of health care as individual responsibility. ${ }^{12}$ On the other side of the aisle, Massachusetts

7. Mass. Plan, supra note 5.

8. MintZ, LeVIn, COHN, Ferris, Glovsky \& Popeo, P.C., HeAlTh Alert: MassachusetTS ENACTS LANDMARK HEALTH CARE REFORM BILL: AN OVERVIEW OF H. 4850, "AN ACT PROVIDING ACCESS TO AFFORDABlE, QUalitY, ACCOUNTABle HEALTH CARE" (2006), http:/www.mintz. com/newsletter/2006/Health-Alert-Landmark-Reform-Bill-4-13-06/index.htm [hereinafter HEALTH ALERT].

9. See generally KAISER COMM'N ON MEDICAID \& THE UNINSURED, THE HENRY J. KAISER Family Found., Key Facts: MassachuSETTS HeALTH CARE REFORM PLAN (2006), available at http://www.kff.org/uninsured/upload/7494.pdf (providing an overview of the Plan); Massachusetts Health Care Reform, L. WATCH (Foley \& Lardner LLP, multiple locations), May 31, 2006 (same); Holahan \& Blumberg, supra note 4, at w432, (discussing the passage of the Plan and its potential for success); HEALTH ALERT, supra note 8 (same).

10. See Elizabeth Mehren, Expansive Health Plan Won't Fit All States, L.A. TimEs, Apr. 8, 2006, at A5 (quoting head of Galen Institute, Washington health policy research group, observing that Massachusetts managed to "slice up the problem" of health insurance coverage).

11. See Could Massachusetts Take the Lead on the Path to Health Care Reform?, STATE HEALTH WATCH, Aug. 1, 2006, available at 2006 WLNR 12418755 [hereinafter STATE HEALTH WATCH] (suggesting that single-payer plan would be more efficient, with lower administrative costs); see also Rashi Fein, Universal Health Insurance-Let the Debate Resume, 290 JAMA 818, 818 (2003) (revisiting the universal health care issue a decade after the failed Clinton plan); The Physicians Working Group for Single-Payer Nat'l Health Ins., Proposal of the Physicians' Working Group for Single-Payer National Health Insurance, 290 JAMA 798, 799 (2003) (suggesting private sector resolutions would be a disaster under current extravagant health care utilization); Anna Bernasek, Health Care Problem? Check the American Psyche, N.Y. TIMES, Dec. 31, 2006, § 3, at 3 (arguing for single-payer system).

12. See Holahan \& Blumberg, supra note 4, at w443 ("Achieving universal coverage anywhere will clearly require an individual mandate even if an employer mandate is also part of a state's reform."); John E. McDonough et al., The Third Wave of Massachusetts Health Care Access Reform, 2006 HEALTH AFF.: WEB EXCLUSIVES w420, w424 (noting that establishment of "'individual responsibility"' for health insurance is "[a] controversial and unprecedented aspect of Chapter 58"); Nancy C. Turnbull, The Massachusetts Model: An Artful Balance, 2006 HEALTH AFF.: WeB EXCLUSIVES w453, w454 (noting Massachusetts's history of viewing lack of health insurance as shared problem and that new Plan "is a fundamental cultural shift" that makes health insurance purchase "an individual responsibility"); Gloria Gonzalez, Massachusetts Reform Praised Amid Concerns, Bus. INS., June 19, 2006, at 4 (noting that insurers praise emphasis on individual responsibility because residents who can afford to purchase insurance should and quoting Charles Baker, President and Chief Executive Officer of Harvard Pilgrim Health Care Inc., who described the plan as "terrific"); Mehren, supra note 10 (noting that the plan emphasizes individual responsibility); Mitt Romney, Health Care for Everyone? We've Found a Way, WALL ST. J., Apr. 11,2006 , at A16 ("Some of my libertarian friends balk at what looks like an individual mandate. But remember, someone has to pay for the health care that must, by law, be provided: Either the 
had an overwhelmingly Democratic state legislature and strong patient and consumer advocacy groups, advocating the view that health care is a right. ${ }^{13}$ A successful comprehensive approach to health reform would have to bridge that wide divide. ${ }^{14}$

The Massachusetts Plan relies on a patchwork of existing and expanded private and public health insurance systems. The Plan requires employers to either provide health insurance for their employees or pay a fixed penalty or surcharge into the state uninsured care pool of funds. It also requires individuals to purchase health insurance, much like mandatory automobile liability insurance, either through employer plans or individually. State subsidies are available for residents falling below designated income levels. In addition, the state will coordinate an insurance purchasing pool-the Connector-to address market inequalities that typically make such policies prohibitively expensive for individuals and small employers.

\section{A. Employer "Pay or Play" Requirement}

Beginning January 1, 2007, Massachusetts employers with 11 or more employees are required to "play," that is, to establish and maintain health insurance "cafeteria plans," consistent with state requirements and U.S. Internal Revenue Code $\S 125$, meaning that employees' and employers' contributions to the plan are paid with pre-tax dollars. ${ }^{15}$

individual pays or the taxpayers pay. A free ride on government is not libertarian.").

13. See STATE HEAlth WATCH, supra note 11 (quoting New America Foundation health policy program director, describing Republican governor "shaking hands with a legislature that $\mathrm{I}$ think we would agree is among the bluest of blue" legislatures in the country); Jane Zhang, States Take a New Look at Health Reform, WALL ST. J., May 27-28, 2006, at A4 ("'If Ted Kennedy and the overwhelmingly Democrat legislature in Massachusetts can come to an agreement with a Republican governor around the idea of private health insurance plans, then Vermont should be able to do it, too."' (quoting Vermont governor's spokesperson)); see also Uwe E. Reinhardt, Reforming the Health Care System: The Universal Dilemma, 19 AM. J.L. \& MED. 21, 22 (1993) (describing the "spectrum of views" from health care as "essentially a private consumption good, whose financing is the responsibility of its individual recipient" or "a social good that should be collectively financed and available to all citizens who need health care, regardless of the individual recipient's ability to pay for that care"); The Physicians' Working Group for Single-Payer Nat'l Health Ins., supra note 11 , at 799 ("Access to comprehensive health care is a human right. It is the responsibility of society, through its government, to ensure this right.").

14. See STATE HEAlth WATCH, supra note 11 (quoting Commonwealth Fund president Karen Davis, noting "[o]ne particularly cogent lesson" of Massachusetts plan implementation was that it "successfully brought together numerous players from across the political, business, health care delivery, and policy sectors")

15. Mass. Plan, supra note $5, \S 47(a)$ (defining "contributing employer" as "an employer that offers a group health plan, as defined in 26 U.S.C. $5000(\mathrm{~b})(1)$, to which the employer makes a fair and reasonable contribution"); id. $\S 47($ b) (defining "pay" requirement for employers with eleven or more employees). 
Employers can self-insure or purchase health plans through the Connector. In either case, employers are required to make a "fair and reasonable contribution" to the cost of employees' health coverage.

Employers that do not contribute to an employee health plan must instead "pay" into the state uninsured care pool of funds an amount up to $\$ 295$ per employee per year. ${ }^{16}$ The employer's "fair share contribution" is intended to cover a portion of the cost that the state pays for free care used by employees whose employers do not provide health insurance. Employers can offer an entirely employee-paid health plan but still must make the fair share contribution to the state. Although some estimates predict that this employer penalty will generate approximately $\$ 48$ million for the free-care fund, ${ }^{17}$ it seems ripe for abuse if the Plan's intent was to penalize employers for noncompliance with the "play" mandate. Compared to the cost of a comprehensive health plan for an employee, employers may rationally conclude that $\$ 295$ represents a bargain rather than a penalty. It may be that the low fee was a necessary political compromise to get employers on-board with the Plan. The amount also might have been seen as necessary to avoid Employee Retirement Income Security Act ("ERISA") preemption issues because a higher penalty might force employers' hands, running awry of the Travelers "indirect effects" standard. ${ }^{18}$

In addition to the fair share contribution, employers whose uninsured employees access free care must pay a "free rider surcharge." "If any uninsured employee accesses free care more than three times per year, or the employer has five or more instances of employees receiving free care in a year, non-providing employers will be required to pay 10 to $100 \%$ of the state's free care costs. The surcharge is triggered only if employers'

16. Id. $\S 47(\mathrm{c})(10)$ (providing that "total annual fair share employer contribution shall not exceed \$295 per employee"). When Governor Romney signed the health insurance reform bill, he vetoed the employer penalty, but the overwhelmingly Democratic legislature overrode the veto. Robert Steinbrook, Health Care Reform in Massachusetts-A Work in Progress, 354 NEW ENG. J. MED. 2095, 2096 (2006).

17. Jeffery Krasner, Businesses Await Rules for Avoiding Healthcare Levy, BostON GLOBE, June 29, 2006, at A1.

18. Employee Retirement Income Security Act of 1974, 29 U.S.C. $\S 1144(a)$ (2000); see N.Y. State Conference of Blue Cross \& Blue Shield Plans v. Travelers Ins. Co., 514 U.S. 645, 662 (1995) (holding that state insurance laws that have a "connection with" an ERISA plan are preempted, but not state laws that have only indirect economic effects). But see Retail Indus. Leaders Ass'n v. Fielder, 475 F.3d 180, 183, at *1 (4th Cir. 2007) (holding that ERISA preempts Maryland "Fair Share Act," requiring employers with 10,000 or more Maryland employees to spend at least $8 \%$ of payroll on employees' health costs, or pay the amount that spending falls below that level into state fund); Illegal Health Care, WALL ST. J., Jan. 23, 2007, at A1 8 (suggesting that the Retail Industry Leaders decision suggests that the Massachusetts "pay or play" mandate is probably preempted).

19. Mass. Plan, supra note $5, \S 44(a)$. 
uninsured workers annually incur $\$ 50,000$ in free care costs. ${ }^{20}$ In other words, there is a $\$ 50,000$ employer exemption for the free rider surcharge.

\section{B. Individual Mandate}

Another key component of the Massachusetts Plan is the requirement that all residents over age eighteen maintain a minimum level of health insurance, effective July $1,2007 .{ }^{21}$ Just as many states require vehicle drivers to carry a minimum level of liability insurance, Massachusetts now requires all residents to have health insurance. ${ }^{22}$ State standards will specify "creditable coverage," based on an annual premium schedule, published annually on December 1, with age and rate variations. ${ }^{23}$

There are religion, hardship, and, most importantly, "no affordable coverage" exemptions from the individual mandate. ${ }^{24}$ "Affordability" is not defined in the Act but will be set annually by the Connector. ${ }^{25}$ The success or failure of the comprehensive state Plan may turn in large part on the affordability scale. As enacted, the affordability standard and Commonwealth Care Health Insurance Program subsidy scale are not linked. ${ }^{26}$ If the affordability standard is set too high, it will likely overburden the subsidy program. But if it is set too low, the insurance plans offered at that price may be of little value to insureds. ${ }^{27}$

Individuals who fail to comply with the individual mandate face tax penalties. In the first year of the Plan, 2007, the penalty is loss of the personal tax deduction. ${ }^{28}$ In 2008 and thereafter, the penalty is an amount up to $50 \%$ of the cost of an affordable premium. The penalty will be collected first by forfeiture of the individual's tax refund and,

20. Id. $\S 44(\mathrm{~b})$.

21. Id. $\S 12$ (to be codified at MASS. GEN. LAwS ch. $111 \mathrm{M} \S 2(\mathrm{a})$ ).

22. See State Health Watch, supra note 11 (quoting Mike Tanner of the Cato Institute, characterizing individual mandate as "an enormous infringement on individual liberty").

23. Mass. Plan, supra note $5, \S 12$ (to be codified at MASS. GEN. LAws ch. $111 \mathrm{M}, \S 1$ ) (defining "creditable coverage"); id. $\S 101$ (to be codified at MASS. GEN. LAWS ch.176P, $\S 3(\mathrm{p})$ ) (discussing premium schedule).

24. Id. $\S 12$ (to be codified at MASs. GEN. LAws ch. $111 \mathrm{M}, \S \S 3-4$ ).

25. See Holahan \& Blumberg, supra note 4, at w436-37 (discussing possible methods for determining what constitutes "affordability"); Steinbrook, supra note 16, at 2095 (discussing affordability scale and assumptions relating to individual mandate); Gonzalez, supra note 12 (discussing issues to be worked out by regulations, including affordability scale).

26. Holahan \& Blumberg, supra note 4, at w437; see also infra Part III.C (discussing Commonwealth Care Health Insurance Program, or "CCHIP").

27. See infra Part IV.B.4 (describing Connector vulnerabilities and "name only" coverage).

28. Mass. Plan, supra note $5, \S 12$ (to be codified at MASS. GEN. LAWS ch. $111 \mathrm{M}, \S 2$ (b)). 
then, direct assessment for the balance. ${ }^{29}$ As with the employer "pay" penalty, the penalty for failing to comply with the individual insurance mandate is relatively low. Paying a tax penalty in the amount of half the annual cost of affordable individual coverage - the cheapest available plan-may seem like a reasonable alternative to individuals who chose to "go bare" and not to carry any insurance.

\section{Commonwealth Care Health Insurance Program}

For individuals who cannot afford to purchase health insurance, the Massachusetts Plan includes state subsidies through the Commonwealth Care Health Insurance Program (CCHIP). ${ }^{30}$ Subsidies are available for low-income individuals not otherwise eligible for Medicaid or the State Children's Health Insurance Program (SCHIP). ${ }^{31}$ Only Commonwealth residents, not undocumented immigrants or others residing temporarily or illegally in the state, may receive state subsidies to comply with the individual mandate. $^{32}$ The subsidized state plans cover inpatient, outpatient, preventative care, prescription drugs, mental health and substance abuse treatment, and dental care. ${ }^{33}$

Residents with incomes below $100 \%$ of the federal poverty level (FPL) ${ }^{34}$ receive insurance through the Connector with no premiums or deductibles, and only modest copayments. ${ }^{35}$ Copayments on prescription drugs and emergency room visits will be set at Medicaid-level. Residents with income between 100 and $300 \%$ of $\mathrm{FPL}^{36}$ also qualify for premium subsidies based on a sliding fee scale, which has not yet been established. ${ }^{37}$ There is no deductible for any Connector-subsidized plan, but all state mandatory coverage rules apply. ${ }^{38}$

29. Id.

30. Id. $\S 45$ (to be codified at MASS. GEN. LAws ch. $118 \mathrm{H}, \S 2$ ) (establishing CCHIP "[f]or the purpose of reducing uninsurance in the commonwealth").

31. Id. $\S 45$ (to be codified at MASS. GEN. LAWS ch. $118 \mathrm{H}, \S 3(\mathrm{a})(3)$ ).

32. Id. $\S 45$ (to be codified at MASS. GEN. LAws ch. $118 \mathrm{H}, \S 3(\mathrm{a})(2))$ (restricting eligibility to an individual who "has been a resident of the commonwealth for the previous 6 months").

33. Id. $\S 45$ (to be codified at MASS. GEN. LAwS ch. $118 \mathrm{H}, \S 6(\mathrm{a})$ ).

34. One hundred percent of FPL for an individual is approximately $\$ 9800$ annual income. KAISER COMM'N ON MEDICAID \& THE UNINSURED, supra note 9, at 1.

35. Mass. Plan, supra note $5, \S 45$ (to be codified at MASS. GEN. LAWS ch. $118 \mathrm{H}, \S 6$ (b)).

36. Three hundred percent of the FPL for a family of three is approximately $\$ 49,800$ annual income. KAISER COMM'N ON MEDICAID \& THE UNINSURED, supra note 9, at 1 .

37. Holahan \& Blumberg, supra note 4, at w436.

38. See Tom Miller, Massachusetts: More Mirage than Miracle, 2006 HEALTH AFF.: WEB EXCLUSIVES w450, w451 ("Plans purchased by state-subsidized consumers cannot include any deductibles, but every current state-mandated benefit must be included."). 


\section{The Connector}

The Connector is a particularly intriguing private-market, quasigovernmental element of the Massachusetts Plan. To facilitate compliance with the new health insurance mandates, individuals and employers with fifty or fewer employees can purchase insurance through the Connector. ${ }^{39}$

For individuals above $300 \%$ of FPL, there are no government subsidies for plans purchased through the Connector, but those individuals can pool their purchasing power with others, including small employers, to bargain for more favorable rates than insurers would otherwise offer. $^{40}$ In addition, Connector plans are portable, meaning that individuals maintain coverage without interruption as they change jobs or experience gaps in employment. ${ }^{41}$ Lastly, workers with multiple employers, such as temporary or part-time employees, can combine the employers' contributions to their premiums.

The Connector negotiates and contracts with health care providers, bringing bargaining strength and risk-pooling advantages to the table. The Connector also bargains for CCHIP plans. ${ }^{42}$ In addition, the Connector offers specially designed products for young adults, aged nineteen to twenty-six. ${ }^{43}$ Young adults, including students and persons beginning careers, represent a significant portion of the uninsured. ${ }^{44}$

The Connector is managed by the Commonwealth Health Insurance Connector Authority (Authority) and has an eleven-member board of public and private members. ${ }^{45}$ The Authority also manages CCHIP

39. Mass. Plan, supra note $5, \S 101$ (to be codified at MASS. GEN. LAwS ch. $176 \mathrm{Q}, \S 1$ (defining "eligible small groups" as employing "at least one but not more than 50 employees" and "eligible individuals" as an individual "not offered subsidized health insurance by an employer with more than 50 employees"); $\S 4$ (regarding individual participation); $\S 6$ (regarding small group participation)).

40. See Len M. Nichols, New Am. Found., HeAlth Reform MASSAChuSETtS Style: INK BLOT TEST AND EXAMPLE FOR US ALL 1 (2006), available at http://www.newamerica.net/files/ Doc_File_3030_1.pdf (discussing how the new purchasing pool will combine the small group and non-group insurance markets under one set of regulations).

41. McDonough et al., supra note 12, at w424 (describing features of the Connector).

42. Holahan \& Blumberg, supra note 4 , at $\mathbf{w} 438$ (stating that participation will initially be limited to four specified managed care organizations providing coverage to government-funded programs).

43. Mass. Plan, supra note 5, $\S 90$; see also HEALTH ALERT, supra note 8 (stating that " $19-26$ year-olds will be eligible for new, lower-cost, specially designed products offered through the Connector").

44. Holohan \& Blumberg, supra note 4 , at w436

45. Mass. Plan, supra note 5, $\S 101$ (to be codified at MASS. GEN. LAwS ch. 176Q, $\S 2$ (a) (establishing Authority); $\S 2$ (b) (specifying size and composition of board)). 
subsidized plans. Its other responsibilities include issuing "good housekeeping" seals of approval for health plans offering high quality, low cost products, ${ }^{46}$ certifying that "affordable" coverage is available for individuals, and certifying health plans as "creditable coverage.",47

Plans sold through the Connector must offer all state-mandated benefits, of which there are many-mental health, maternity, and chiropractic, to name a few. ${ }^{48}$ Governor Romney's proposed version of the Plan would have exempted Connector plans from the mandatory coverage requirements. ${ }^{49}$ Instead, lawmakers enacted a one-year moratorium on new mandatory coverage requirements through $2008 .^{50}$ Otherwise, there is no standardized benefit package for Connector plans. $^{51}$ To be affordable, the expectation is that most plans available through the Connector will offer low premiums but high deductibles, high cost-sharing requirements, and limited provider networks. ${ }^{52}$

\section{E. Section 1115 Medicaid Waiver}

Another key feature of the Massachusetts Plan is continuation of the state's existing expanded Medicaid program. Medicaid is a joint federalstate health care program for the needy. States that comply with certain broad federal guidelines are eligible for federal matching dollars. ${ }^{53}$ The federal Medicaid statute requires participating state Medicaid program eligibility up to $200 \%$ of FPL. ${ }^{54}$ States may, however, expand their coverage beyond the federal limit and receive matching dollars for the additional enrollees under individually negotiated waivers, so-called $\S$ 1115 waivers. ${ }^{55}$ Section 1115 waivers allow states to experiment with their Medicaid programs, but the waiver program must be budget-neutral

46. Id. $\S 101$ (to be codified at MASS. GEN. LAwS ch. 176Q, § 3(a)(3)).

47. Id. $\$ 101$ (to be codified at MASS. GEN. LAws ch. 176Q, $\S 3(\mathrm{~s})$ ).

48. Holahan \& Blumberg, supra note 4, at w434-35.

49. Id. at $\mathrm{w} 433$

50. Mass. Plan, supra note $5, \S 127$.

51. Holahan \& Blumberg, supra note 4 , at w438.

52. Id; see infra Part IV.A (describing characteristics of Connector plans).

53. Federal matching assistance percentages (FMAP) range from fifty to seventy-five. Massachusetts typically receives a 50\% FMAP. See Federal Financial Participation in State Assistance Expenditures; Federal Matching Shares for Medicaid, the State Children's Health Insurance Program, and Aid to Needy Aged, Blind, or Disabled Persons for October 1, 2006 Through September 30, 2007, 70 Fed. Reg. 71,856, 71,857 (Nov. 30, 2005) (providing Massachusetts percentage for 2007).

54. 42 U.S.C. $\S 1396 \mathrm{~d}(\mathrm{~s})(2)(2000)$.

55. See Steinbrook, supra note 16, at 2097 (describing $\S 1115$ waivers); see also STATE HEALTH WATCH, supra note 11 (discussing states as laboratories); Zhang, supra note 13 (noting that federal government's expected actions have encouraged state experimentation with health coverage). 
for federal contribution. ${ }^{56}$ The Centers for Medicare and Medicaid Services (CMS), Office of Management and Budget (OMB), and specially appointed House and Senate appointees must approve the proposal. ${ }^{57}$

Massachusetts had in place a $\S 1115$ waiver expanding Medicaid eligibility to $300 \%$ of FPL. ${ }^{58}$ That waiver, which represented $\$ 385$ million dollars in federal revenue for state health coverage, was set to expire in 2007. The potential loss of substantial federal health care funding was a significant driver in bringing lawmakers from opposite ends of the political spectrum together to enact the Plan. ${ }^{59}$ The success or failure of universal coverage in Massachusetts seemed to rest on renewing the waiver. ${ }^{60}$

In addition to continuing expanded eligibility, the waiver renewal submitted to federal authorities for approval included direct subsidies to safety-net hospitals, shifted insurance subsidies for uninsured residents, and improved outreach efforts to increase enrollment of eligible residents. Other Medicaid changes in the Plan include increasing Medicaid reimbursement rates for hospitals and physicians from the current level of 80 to $95 \%$ of costs. ${ }^{61}$ Increased reimbursement was likely considered necessary to ensure that providers continue to participate in the Medicaid program. For most providers, Medicaid participation is voluntary; they do not have to accept Medicaid patients

56. See generally 42 U.S.C. $\$ 1315$ (2000) (describing demonstration projects); Centers for Medicare \& Medicaid Services, Research \& Demonstration Projects - Section 1115, http://www. cms.hhs.gov/MedicaidStWaivProgDemoPGL/03_Research\&DemonstrationProjects-Section 1115 .asp (last visited May 31, 2007) ("Demonstrations must be "budget neutral' over the life of the project, meaning they cannot be expected to cost the Federal government more than it would cost without the waiver.").

57. See Charles Milligan, Acad. for Health Servs. Research \& Health Policy, Section 1115 Waivers and Budget Neutrality: Using Medicaid Funds to Expand Coverage 3 (2001), available at http://www.statecoverage.net/pdf/issuebrief501.pdf (describing approval process); see also McDonough et al., supra note 12, at w429-30 (describing Massachusetts's negotiations with CMS over $\$ 1115$ waiver).

58. See State Health WATCH, supra note 11 (discussing Medicaid expansion).

59. See McDonough et al., supra note 12, at w429 (noting significance of waiver's expiration to Massachusetts health reform process); Mehern, supra note 10 (citing Representative DiMasi's statement that "lawmakers wanted to take advantage of a brief federal funding window that guaranteed \$385 million in annual subsidies"); see also Pamela A. Paul-Shaheen, The States and Health Care Reform: The Road Traveled and Lessons Learned from Seven That Took the Lead, $23 \mathrm{~J}$. HEALTH POL. POL'Y \& L. 319, 326-27 (1998) (describing the health care funding "crisis" as a "catalyst" for successful reform efforts).

60. See Holahan \& Blumberg, supra note 4, at w433 (suggesting that success of a comprehensive plan would be hard to imagine without the waiver); Steinbrook, supra note 16, at 2096-97 (noting that implementation depends on many assumptions, including Medicaid waiver approval).

61. McDonough et al., supra note 5, at w426. 
and may decline to do so if reimbursement is too low. The cost of increased Medicaid reimbursement is estimated at $\$ 540$ million, ${ }^{62} \$ 90$ million of which would be drawn from the Commonwealth Care Trust Fund. ${ }^{63}$ After two years, hospitals must meet certain quality benchmarks to continue receiving the rate increases. ${ }^{64}$

\section{F. Dependent Child "Piggybacking"}

Another provision of the plan aimed at closing a potential gap in the private insurance market. Family health insurance plans must maintain coverage for young adults on parents' policies for two additional years after loss of dependent status, or until age 25 , whichever occurs first. ${ }^{65}$

\section{G. Tax Incentives}

As noted above, employee and employer contributions to employersponsored group health plans are tax-exempt, under Internal Revenue Code (IRC) $\S 125$ and state tax laws. ${ }^{66}$ That tax benefit is expected to reduce individual insurance costs for Massachusetts residents by $25 \%{ }^{67}$ The Bush Administration, however, is considering changes to the tax benefit for employer plans to shift the incentive to health savings accounts and individual health plan purchases on the open market. ${ }^{68}$ The savings generated by reducing the existing tax benefit "would be used to pay for tax credits for lower-income people who buy their own health insurance [through state pools, like the Connector,] or for state insurance pools, or both."69 Under the Massachusetts Plan, Connector health insurance premiums receive pre-tax treatment under state law. ${ }^{70}$

62. Id. at $\mathbf{w} 422$.

63. See id. at w426 (stating that payments to hospitals and physicians from MassHealth will increase by $\$ 90$ million).

64. Id.

65. Mass. Plan, supra note $5, \S 49$; see McDonough et al., supra note 12 , at w426 (regarding insurance market changes).

66. See Holahan \& Blumberg, supra note 4, at w434 (describing federal tax treatment for employee health insurance premiums); supra notes 15-16 and accompanying text (describing employer pay-or-play responsibility)

67. See STATE HEALTH WATCH, supra note 11.

68. Lynn M. Etheredge, Massachusetts Reform Plus President Bush's Tax Credits: A National Model, 2006 HeAlTH AfF.: WeB ExCLusives w444, w444-45; Robert D. Reischauer, Benefits with Risks-Bush's Tax-Based Health Care Proposals, 356 NEw ENG. J. MED. 1393, 1393 (2007).

69. John D. McKinnon \& Deborah Solomon, Bush Plots Health-Care Push, WALL ST. J., Jan. 16,2007 , at A6; see Etheredge, supra note 68, at w445 (noting that proposed federal tax credit could funnel additional $\$ 150$ million into Massachusetts budget).

70. See Holahan \& Blumberg, supra note 4, at w435 (noting tax benefit for Connector plans); 
In addition, Massachusetts gives state tax exemption to individual contributions, expenditures, and earnings under Health Savings Accounts (HSAs), consistent with existing federal tax treatment of HSAs. The Bush proposal would add an individual deduction for health care premium payments, whether employer-based or individual policies, up to a specified amount. The goals of the proposal are to encourage currently uninsured individuals to purchase insurance, make individual insurance more affordable, and reduce the present skewed incentives toward employer-based coverage. ${ }^{71}$

\section{H. Uncompensated Care Fund}

The Massachusetts Plan eliminates the state's existing uncompensated care pool and replaces it with the Health Safety Net Fund. $^{72}$ For the first year, fiscal year 2007, the Fund will receive the same state funding level as it did in fiscal year 2006. After 2007, the only identified funding will come from payor and hospital assessments, perhaps with the optimistic view that universal coverage will be achieved and uncompensated care will no longer be as necessary. ${ }^{73}$ In any event, there is no assurance of continued state support, in light of new mechanisms to ensure near-universal insurance coverage.

\section{THE MASSACHUSETTS MODEL}

To predict whether the Massachusetts Plan will succeed and whether its features can be exported to other states, it is useful to review previous Massachusetts health reform efforts. In addition, states looking to the Massachusetts model for guidance should scrutinize unique characteristics of that state and the context in which the health reform debate occurred, and which factors may make the Massachusetts Plan workable there but could pose difficulties for exporting the model to other jurisdictions.

STATE HEALTH WATCH, supra note 11 (suggesting that tax benefits could reduce Connector premium costs by $25 \%$ ).

71. See Etheredge, supra note 68 , at $\mathbf{w} 444$ (describing anticipated Bush proposal in conjunction with Massachusetts Plan).

72. See STATE HEALTH WATCH, supra note 11 (noting October 1, 2007, implementation date for change).

73. See Holahan \& Blumberg, supra note 4, at w442 (estimating $\$ 175$ million increase in state revenues from employer assessment, free-rider surcharge, and general revenues). 


\section{A. Previous Efforts in Massachusetts}

The 2006 Plan is Massachusetts's fourth wave of state health care reform. First, in 1985, the state established the existing uncompensated care pools, funded in part through provider surcharges. ${ }^{74}$ The uncompensated care fund was a piece of a larger reform package focused on rate controls. The hospital ratemaking is now deregulated in Massachusetts, leaving hospital pricing to the free market, but the uncompensated care pools remain, funded with a combination of federal, state, hospital, and insurer contributions.

In 1988, Governor Dukakis enacted a universal care law that was never fully implemented. Most provisions were repealed when Dukakis lost to the state's first Republican governor, William Weld. ${ }^{75}$ The law sought to achieve near-universal coverage by $1992 .^{76}$ The key provision was an employer play-or-pay mandate on employers with six or more employees. 77 The "pay" penalty for nonparticipating employers was $\$ 1680$ per year per uninsured worker. ${ }^{78}$ Governor Weld repealed the employer mandate, with little resistance, given nationwide economic downturn, tepid legislative support for the plan, and implementation delays. ${ }^{79}$ Instead, the state enacted a tobacco tax to fund health reform. ${ }^{80}$

Some pieces of the 1988 reform package were left in place, however, including the CommonHealth program, which extended Medicaid to disabled adults returning to work and certain disabled children. ${ }^{81}$ Also, the Medical Security Plan, a business levy of $\$ 16.80$ per worker to fund unemployment compensation, was retained. ${ }^{82}$ The Healthy Start Program, which provides health insurance coverage to low-income

74. See David MacKenzie \& Barbara Diamond, Health Care Reform: Reflections on the Massachusetts Experience, BoSTON B.J., May/June 1994, at 7, 8 (noting that 1985 legislation created uncompensated care pool for the uninsured and imposed a surcharge on "hospital bills paid by Blue Cross, commercial insurers, HMO's, and private individuals, in an amount sufficient to offset the free care and bad debt costs of all hospitals").

75. See id. at 7 (reflecting on Massachusetts's 1988 health care law, Chapter 23); Miller, supra note 38, at w450 (describing 1988 attempt at universal state health care); Steinbrook, supra note 16, at 2096 (describing controversial 1988 universal health care law).

76. McDonough et al., supra note 12 , at w421.

77. Id.

78. Id.

79. Id.

80. Id.

81. Id.

82. Id. 
women and new mothers, remains. ${ }^{83}$ In addition, college and university students were and continue to be required to purchase health insurance. ${ }^{84}$

In 1997, Massachusetts negotiated its first $\S 1115$ Medicaid waiver, which had the effect of expanding MassHealth coverage from 670,000 residents in 1995 to $1,038,000$ today. ${ }^{85}$ After the Medicaid expansion was implemented, the number of uninsured in the state dropped from 680,000 in 1995 to 365,000 in $2000{ }^{86}$ Coverage for children under the State Children's Medical Security Plan was also expanded. ${ }^{87}$

The current Plan, enacted in 2006, went through several versions. Initially, Governor Romney vetoed the employer "fair share contribution" penalty, but the legislature overrode the veto. There were also proposals to exempt employers that provided any minimal, rather than "fair and reasonable," contribution, which were rejected. ${ }^{88}$ Others proposed a minimum employer contribution, e.g., $50 \%$ of the cost of employees' health plans, but that too was rejected. ${ }^{8}$

Romney also proposed exempting high deductible, limited coverage plans from the state mandatory coverage requirements. ${ }^{90}$ Some commentators suggested that an effective approach to reduce the cost of health insurance would be to allow variation in plan coverage because consumers would pay only for the coverage that they expect to use. ${ }^{91}$ But Massachusetts rejected the proposal to exempt Connector plans from existing mandatory coverage laws, instead promoting highpremium/high-deductible plans as the affordable alternative to comprehensive coverage. The Plan does include a moratorium on new mandatory coverage provisions for the first year of implementation.

83. Id.

84. Id.

85. 1 d.

86. Id.

87. Id.

88. See Krasner, supra note 17 (discussing the difference between a bill that authorizes "fair and reasonable" contributions and one that would have authorized minimal contributions).

89. See id. (discussing a higher standard for employer contributions of "at least 50 percent of the premium").

90. Holahan \& Blumberg, supra note 4 , at w439.

91. See, e.g., David R. Henderson, Terminatorcare, WALL ST. J., Jan. 10, 2007, at A17 (suggesting that abolishing expensive mandatory coverage for chiropractic care, alcoholism and drug abuse, mental health, and infertility "would allow people who don't want to be covered for these things to buy cheaper insurance, while still allowing those who want them to buy and pay for them"). 


\section{B. Unique Characteristics of Massachusetts}

Various features of Massachusetts's politics, population, and business climate facilitated passage of the landmark legislation. Whether that particular constellation of factors is a necessary precondition for other states considering similar reforms is very much an open question. ${ }^{92}$

First, the state has a relatively small, homogenous populationapproximately 6.4 million. ${ }^{93}$ Also, the state level of uninsured residents is relatively low, compared to nationwide averages. Before the Plan's enactment, approximately 550,000 , or $10 \%$ of Massachusetts residents were uninsured, compared to $16 \%$ nationwide. ${ }^{94}$ In addition, $59.5 \%$ of Massachusetts residents had employer health coverage. ${ }^{95}$ Observers anticipate that 35,000 people in Massachusetts will remain uninsured after the Plan's enactment. ${ }^{96}$

Another arguably necessary political expedient to the Plan's passage was the threatened expiration of substantial federal funding. Massachusetts's 1997 Medicaid $\S 1115$ waiver, which expanded state Medicaid coverage to children and the working poor, was about to expire, representing a potential loss of $\$ 385$ million federal revenue. ${ }^{97}$ That threat may have been the impetus for lawmakers with drastically differing views on health care reform to come together and preserve the funding. ${ }^{98}$

92. See Elizabeth A. McGlynn \& Jeffery Wasserman, Massachusetts Health Reform: Beauty Is in the Eye of the Beholder, 2006 HEALTH AFF.: WEB EXCLUSIVES w447, w447 (urging that "the starting point matters" for other states considering similar reform and noting unique characteristics of Massachusetts); Mehren, supra note 10 (noting small state, 10\% uninsured, low unemployment, and large base of employers offering health coverage); Miller, supra note 38, at w450 ("An equivalent harmonic convergence of the above [unique characteristics] remains far less likely in other states considering similar coverage expansion initiatives.").

93. McDonough et al., supra note 12, at w421.

94. Id. at w430 (citing $11 \%$ Massachusetts and $16 \%$ nationwide uninsured figures); Steinbrook, supra note 16, at 2095 (same); see also STATE HEALTH WATCH, supra note 11 (7\% compared to $15 \%$ ). The expected impact of the Massachusetts plan is to bring 515,000 currently uninsured Massachusetts residents under coverage, reducing the current number of uninsured in Massachusetts, estimated at 550,000 (or 715,000, according to some estimates) to close to 35,000 . William C. Symonds, In Massachusetts, Health Care for All?, BUS. WK. ONLINE, Apr. 4, 2006, http:// www.businessweek.com/print/investor/content/apr2006/pi20060404_152510.htm; see also KAISER COMM'N ON MEDICAID \& THE UNINSURED, supra note 9, at 1 (showing pie-chart).

95. Steinbrook, supra note 16, at 2097; see also KAISER COMM'N ON MEDICAID \& THE UNINSURED, supra note 9 , at 1 (citing $68 \%$ figure).

96. KAISER COMM'N ON MEDICAID \& THE UNINSURED, supra note 9, at 1 .

97. See Holahan \& Blumberg, supra note 4, at w432-33 (discussing Medicaid waiver background and impetus for reform).

98. See id. at 443 (describing the competing proposals of the governor, house, and senate); Zhang, supra note 13 (noting factors facilitating bipartisan solution). 
Massachusetts also already boasted an ample uncompensated care fund, in place since $1985 .{ }^{99}$ The fund, supported by both state funding and provider surcharges, contained several million dollars to support hospitals serving the poor. Under the 2006 Plan, most of those funds could be redirected to subsidizing insurance for low-income residents. ${ }^{100}$

Perhaps most importantly for the Plan's eventual success, Massachusetts has a highly regulated insurance market. ${ }^{101}$ In addition to extensive mandatory coverage provisions for health insurance plans sold in the state, ${ }^{102}$ Massachusetts has guaranteed issue, meaning that insurers are prohibited from refusing to sell plans based on pre-existing conditions of the insured. ${ }^{103}$ Also, the state mandates modified community rating, meaning that insurers must offer plans with prices based on overall community risk, rather than on individual risks or experience with the insured-so-called "experience rating."104 Those laws facilitate the "affordability" of plans and residents" ability to comply with the individual mandate because they effectively mandate broad risk-pooling, and prohibit by insurers from cherry-picking risks and insureds from purchasing customized coverage based on individual preferences.

The overall effect of Massachusetts's existing insurance laws is redistribution of health care costs. In an unregulated insurance market, sicker people who are more likely to use health care would end up paying more for their health insurance than healthier people who do not require extensive medical treatment. But Massachusetts's health insurers are prohibited from excluding people who are already sick, pricing their

99. See Tumbull, supra note 12, at w455 (noting the state's long history of "a strong and relatively well-funded safety net").

100. See Holahan \& Blumberg, supra note 4 , at w436 (describing safety-net providers and funds); MacKenzie \& Diamond, supra note 74 , at 8 (discussing history of uncompensated care pool).

101. See Chris Sinacola, Is It Reform or Socialist Nightmare? Health Care Bill May Tax Limits of Freedom, WoRCESTER TElegram \& GAZETTE (Mass.), Apr. 13, 2006, at B1 (noting Massachusetts's highly regulated market, including guaranteed-issue and community-rating laws).

102. See supra notes $90-91$ and accompanying text (discussing mandatory coverage).

103. McDonough et al., supra note 12, at w426, w430.

104. Minor rate variations may be allowed for certain high-risks, e.g., smokers, or for customers meeting certain healthy lifestyle standards. Mass. Plan, supra note $5, \S 82(a)(5)-(6)$ (allowing rate adjustments for wellness programs and tobacco use). See generally Ann Hilton Fisher, Small Employers and the Health Insurance Needs of Employees with High Health Care Costs: A Need for Better Models, 8 EMP. RTS. \& EMP. POL'Y J. 53, 77-78 (2004) (listing states, including Massachusetts, requiring community rating); Mark A. Hall, The Competitive Impact of Small Group Health Insurance Reform Laws, 32 U. MICH J.L. REFORM 685, 710 (1999) (describing insurers' reaction to community rating rules); Olympia J. Snowe, Small Business Health Plans: A Critical Step in Solving the Small Business Health Care Crisis, 43 HARV. J. ON LEGIS. 231, 238 (2006) (discussing modified community rating). 
policies based on expected risk, or selling customers only the type of coverage that they expect to use. Healthy people pay more than they otherwise would, effectively subsidizing sicker people who pay less than they otherwise would.

\section{California Comparison}

As soon as the Massachusetts Plan went into effect in January 2007, other states, notably California, proposed similar patchwork approaches to universal coverage, expanding government programs, imposing new requirements on private industry and individuals, and adding insurance regulations to try to close the uninsured gap.

California Governor Arnold Schwarzenegger's proposal is similar to the Massachusetts Plan in many respects, with some significant differences. ${ }^{105}$ Like Massachusetts, California failed in past attempts to implement health care reform. A 2004 ballot referendum that would have required employers to provide health insurance to their employees failed. ${ }^{106}$ The current proposal includes an employer pay-or-play provision for employers with ten or more employees. Estimates from the Governor's office suggest that $80 \%$ of California employers are small firms and, accordingly, would be exempt. ${ }^{107}$ The California "pay" sanction, payable into the state uninsured pool, is assessed at $4 \%$ of the employer total payroll ${ }^{108}$ instead of the flat $\$ 295$ per employee, as in Massachusetts.

Like Massachusetts, California would require individuals to obtain health insurance, either through an employer, individually, or through the state Connector-type risk pooling mechanism. The individual mandate would be enforceable through not only tax penalties but also wage garnishment. ${ }^{109}$

In addition to requiring employers and individuals to fill the gap, the California plan imposes new requirements directly on health care

105. See All Things Considered: The Massachusetts Health Plan, and California's, (NPR radio broadcast Jan. 10, 2007), available at 2007 WLNR 547932 (describing Governor Schwarzenegger's proposal that "every Californian get health insurance" as risky because "California has more uninsured people than Massachusetts has people").

106. Rachel Gordon, San Francisco City Debates Mandate for Health Benefits, S.F. CHRON., Apr. 21, 2005, at B1.

107. See Associated Press, Arnold's Plan to Stir Debate, WASH. TIMES, Jan. 10, 2007 (describing Califomia plan); Sara Watson Arthurs, Health Plan Brings Praise, Concerns, TIMESSTANDARD (Eureka, Cal.), Jan. 10, 2007 (same).

108. Arthurs, supra note 107.

109. Sonya Geis \& Christopher Lee, Schwarzenegger Proposes Universal Health Coverage, WASH. POST, Jan. 9, 2007, at A3. 
providers and insurers. Providers must pay a tax, or surcharge, in the amount of $2 \%$ of revenues for physicians and $4 \%$ for hospitals. ${ }^{110}$ Massachusetts already exacts a surcharge on providers and insurers to fund the uncompensated care fund. ${ }^{111}$

New California requirements on insurers include guaranteed issue, meaning that insurers cannot discriminate based on age or diagnosis in issuing policies. The proposal also requires insurers to spend at least $85 \%$ of premiums on patient care, limits spending on administrative overhead, and caps profits. ${ }^{112}$ Otherwise, insurers seem pleased with the proposal, anticipating four million to five million new customers. In addition, the plan does not include any caps on premiums or mandatory coverage provisions.

Like Massachusetts, California would expand existing state welfare programs and add subsidies to assist low-income people purchase individual coverage. The state Medicaid program, Medi-Cal, would be expanded to adults up to $100 \%$ of FPL and children, regardless of immigration status, in households up to $300 \%$ of FPL. ${ }^{113}$ California anticipates an additional five billion in federal matching dollars with Medicaid expansion. Subsidies would be available for persons up to $250 \%$ of FPL. Massachusetts, by contrast, does not cover undocumented residents in its expanded Medicaid and extends subsidies up to $300 \%$ of FPL. The California proposal would also increase provider reimbursement under Medi-Cal by $\$ 4$ billion. It is not clear, however, how the provider surcharge and Medi-Cal reimbursement increase would net out.

Whether the Massachusetts and California plans succeed in achieving near-universal coverage for their residents may turn on unique characteristics of each state. There are numerous differences between California and Massachusetts, but a few are worthy of mention. First, California has a much larger, more diverse population, with a greater percentage of undocumented residents than Massachusetts. ${ }^{114}$ The

110. Bill Ainsworth, Governor Wants All Insured, S.D. UNION-TRIB., Jan. 9, 2007, at Al (describing the term "coverage dividend"); Vanessa Fuhrmans, California Gets Healthy Response, WALL ST. J., Jan. 19, 2007, at A10 (describing surcharges).

111. See MASS. GEN. LAwS ANN., ch. 118G, §§ 18, 18A (West Supp. 2007) (describing uncompensated care trust fund and hospital surcharges); 114.6 MASS. CODE REGS. $\S 11.06$ (surcharge payments); see also MacKenzie \& Diamond, supra note 74, at 8 (describing provider and insurer surcharges).

112. See Allen P. Roberts, Jr., Gov. Proposes 'Pay or Play' Health Reform, L.A. Bus. J., Jan. 8, 2007.

113. Jennifer Steinhauer, California Plan for Health Care Would Cover All, N.Y. TIMES, Jan. 9, 2007, at A1.

114. See Mehren, supra note 10 (quoting health policy analyst Laura Tobler of National 
proposal to cover all children, regardless of immigration status, could make the California plan significantly more expensive. California also has a higher level of uninsured, $19 \%$ or 6.5 million people, than Massachusetts, at $11 \%$ and the nationwide average of $16 \%{ }^{115}$ The state has more low-income residents, with approximately $45 \%$ below $300 \%$ of FPL, compared to $28 \%$ in Massachusetts. ${ }^{16}$ Those differences present a greater challenge mandating individual coverage. Another key difference is California's relatively unregulated insurance market, including lack of comprehensive mandatory coverage provisions, guaranteed issue or community rating requirements. Without those laws in place, California's insurance market may fragment into high-risk insureds paying high premiums, rather than the risk spreading effect that exists in the Massachusetts market. States considering similar plans will need to carefully consider whether the unique constellation of factors in Massachusetts is a necessary precondition for successful reform. ${ }^{117}$

\section{CONNECTOR PLANS}

Other Symposium participants have given comprehensive consideration to various features of the Massachusetts Plan. This Article provides a focused critique of one component of the plan-the quasigovernmental risk-pooling conduit, or Connector. First, I describe expected characteristics of health insurance policies offered through the Connector. Then, I identify expected vulnerabilities of those policies for the overall success of Massachusetts's universal coverage objective. Finally, I predict various regulatory and market responses to the Connector's failure.

\footnotetext{
Conference of State Legislatures on differences between California and Massachusetts).

115. STATE HEALTH WATCH, supra note 11 (citing statistics of $20.7 \%$ uninsured in California, compared to $13.1 \%$ in Massachusetts); Jim Carlton, Schwarzenegger Embarks on Fight for Health Plan, Wall ST. J., Jan. 9, 2007, at A2 (comparing Califomia rate of uninsured, at $19.4 \%$, to nationwide average of $15.9 \%$ ).

116. STATE HEALTH WATCH, supra note 11 (comparing California and Massachusetts low or modest income levels).

117. See, e.g., Bolder Could Make Health Care Reform Better, Portland PRESS-HERALD, Apr. 15, 2006, at A7 (comparing the Massachusetts Plan and Maine's Dirigo Health initiative); M. William Salganik, Universal Health Care: Can It Work Here? Shared Responsibility is Key to Bay State's Compromise, BALT. SUN, Apr. 20, 2006, at 1D (discussing the Massachusetts Plan and health care reform in Maryland); Zhang, supra note 13.
} 


\section{A. Characteristics of Connector Plans}

Plans sold through the Connector can be expected to share certain characteristics. The goal is to make health insurance affordable for individual and small group purchasers to facilitate compliance with the individual and employer mandates. Accordingly, Connector plans will likely have low premiums, in the neighborhood of forty to sixty dollars per month for individual coverage. ${ }^{118}$ Individuals who previously have "gone bare," with no health insurance, due to unaffordability or low riskaversion, will likely be drawn to plans with low upfront costs. The most expedient way for insurers to offer low premium plans is to require high cost-sharing by policyholders. Deductibles could be expected to be approximately $\$ 1000$ to $\$ 5000$ for individuals, or $\$ 2500$ to $\$ 10,000$ for families. ${ }^{119}$

In addition, consumers should expect steep copayments on Connector plans. Copayments are the classic health insurance approach to patient moral hazard, that is, the tendency to seek more health care when insured than when paying out of pocket. Third-party insurance health plans shield patients from the "true costs" of the medical care that they receive. Copayments are designed to make patients think carefully before seeking medical care and appreciate the costs. ${ }^{120}$

In addition, Connector plans will likely offer insureds limited networks that exclude high-cost providers. Plans will also limit coverage to the extent allowable under Massachusetts's mandatory coverage and other insurance regulations. Although Connector plans must comply with existing state mandatory coverage requirements, there is no standardized benefit package, making it difficult for consumers to

118. See Holahan \& Blumberg, supra note 4, at w435, w438 ("The intent is that the Connector would hold down premiums by having plans with relatively high cost-sharing requirements and limited provider networks.").

119. See id. at w435, w439 (characterizing high deductible plans); Michele Melden, Guarding Against the High Risk of High Deductible Health Plans: A Proposal for Regulatory Protections, 18 LOY. CONSUMER L. REV. 403, 405 (2006) (characterizing High Deductible Health Plans (HDHPs) as plans with deductibles above $\$ 1000$ ).

120. See Melden, supra note 119, at 413 (noting the term moral hazard refers to "the fact that an individual is likely to incur greater costs when someone else is financially responsible"); Malcolm Gladwell, The Moral-Hazard Myth, THE NEW YoRKER, Aug. 29, 2005, at 44, 46, available at http://www.newyorker.com/printables/fact/050829fa_fact ("[W] requires that you make a twenty-dollar co-payment ... or when your plan includes an annual fivehundred-dollar or thousand-dollar deductible, it's not simply an attempt to get you to pick up a larger share of your health costs. It is an attempt to make your use of the health-care system more efficient."). 
compare costs and coverage. ${ }^{121}$ Moreover, insurers may include "hidden" or surprise exclusions or limits, such as a strict, annual fourvisit limit on primary care physician appointments or specialist referrals, or exclusions of common benefits, such as prescription drugs.

Connector plans may also be combined with HSAs to garner federal and state tax benefits. The Medicare Modernization Act of 2003 included certain changes to the Internal Revenue Code to provide tax benefits to HSAs combined with High Deductible Health Plans (HDHPs) meeting certain requirements. ${ }^{122}$ Individual contributions to HSAs receive pre-tax treatment. In addition, HSA expenditures and earnings are tax-exempt. The Massachusetts Plan extends state tax benefits to HSA contributions as well. Although these plans offer another way for Massachusetts residents to leverage their health care expenditures under the new individual mandate, consumers so far have not made much use of HSA-HDHPs. Among employees offered HSAs through employer plans, one-tenth of employees contribute nothing to the accounts. ${ }^{123}$

\section{B. Connector Vulnerabilities}

In this Article I do not attempt to evaluate the entire Massachusetts Plan but instead focus on the individual and small group market and the Connector. I identify various vulnerabilities with the Connector plans and predict that the device is unlikely to successfully achieve or approach universal coverage. Those market failures will likely require increased government regulation and subsidization to achieve the aim of meaningful insurance coverage for currently uninsured Massachusetts residents.

121. See Holahan \& Blumberg, supra note 4, at w438-39 (discussing problems associated with Connector plans).

122. 26 U.S.C.A. $\$ 223$ (West Supp. 2006). See generally Edward J. Larson \& Marc Dettmann, The Impact of HSAs on Health Care Reform: Preliminary Results After One Year, 40 WAKE FOREST L. REV. 1087, 1097-1100 (2005) (describing HSAs).

123. See Paul fronstin \& Sara R. Collins, Employee Benefit Research inst., Early EXPERIENCE WITH HIgH-DEDUCTIBLE AND CONSUMER-DRIVEN HEALTH Plans: Findings fRom THE EBRI/COMMONWEATH FUND CONSUMERISM IN HEALTH CARE SURVEY 5 (2005), available at http://www.cmwf.org/usr_doc/fronstin_consumerism_survey.pdf (finding that $9 \%$ of the privately insured population ages $\overline{2} 1$ to 64 were enrolled in an HDHP eligible for an HAS but had not yet opened an account). 


\section{Low Take-Up}

The first problem that I anticipate is a low take-up rate for individual or small group coverage, despite the mandates. HDHPs expected to be sold through the Connector traditionally have not been very popular, especially in Massachusetts, where good comprehensive coverage is available. As noted above, HDHPs are characterized by high costsharing, limited networks, and limited coverage, which are turn-offs to people who actually value insurance. For people who previously declined or could not afford insurance, the individual mandate may increase the demand for those types of plans. ${ }^{124}$ If someone is accustomed to no insurance and no monthly premium, a low premium with the possibility of steep out of pocket costs-should he decide to use the coverage-is probably not that different from the status quo ante.

In addition, some individuals may decide that paying the tax penalty is preferable to buying coverage. After the first year, the penalty amounts to $50 \%$ of "affordable" coverage, or the cheapest available plan. Just as employers may rationally determine that paying $\$ 295$ per employee is a better deal than providing coverage, individuals may decide that paying half the cost of a HDHP for no coverage is a better deal than paying the full amount for paltry coverage.

One proposal, which was never pursued, was to sanction individual noncompliance by denying drivers licenses to individuals who do not purchase health insurance, as done with automobile liability insurance. Even that sanction, however, might not substantially increase compliance. The likelihood of individuals rationally choosing not to comply with the individual health insurance mandate seems great, especially when one considers the $15 \%$ nationwide average rate of noncompliance with mandatory automobile liability insurance. By comparison, the nationwide average of people lacking health insurance is

124. Twenty percent of uninsured workers declined employer plans, per KFF 2006 because of premium cost. See Melden, supra note 119, at 421 \& n.85 (citing Kaiser Commission); see also Larson \& Dettman, supra note 122, at 1110-15 (discussing low take-up rates for HSAs). 
$17 \% .^{125}$ Therefore, it is not clear how much would be gained by requiring individuals to purchase health insurance.

\section{Correlation with Employer Mandate}

Another problem with the Connector is that its success seems to inversely correlate with the employer mandate. The better the employer mandate works in terms of covering people through employer plans, the fewer people left purchasing through the Connector. Fewer people mean a smaller risk pool and weaker bargaining position for individuals and small employers. ${ }^{126}$ Smaller risk pools and weaker bargaining power mean higher premiums, making comprehensive coverage less affordable for individuals who seek to purchase it. The Connector does little to alter the existing breakdown of the insurance market, in which the vast majority of Americans, close to 175 million people, have employmentbased insurance, compared to individual insurance purchasers at just over 25 million people. ${ }^{27}$ The already very small individual insurance market will only decrease if the employer mandate succeeds, making it harder for those individuals to negotiate favorable terms with insurers.

Massachusetts's employer "pay or play" requirement addresses the nationwide trend of employers offering less comprehensive health coverage, or discontinuing employer health plans altogether, especially for part-time or temporary workers. Since 2000 , employer health plan premiums have increased by $8.3 \%$, compared with an overall rise in wages of $3.7 \% .^{128}$ From 2000 to 2005 , health insurance costs increased by $73 \%$, while wages rose only $15 \%$ over the same period. ${ }^{129}$ As of

125. See Greg Scandlen, Nat'l Ctr. for Policy analysis, Will Mandatory Health INSURANCE WORK? 1 (2006), available at http://www.ncpa.org/pub/ba/ba569.pdf (noting that all but three states mandate automobile insurance but $14.6 \%$ of drivers remain uninsured and comparing nationwide $17.2 \%$ rate of lack of health insurance); Miller, supra note 38 , at w451 (suggesting that "[c]urrent gaps in compliance with mandatory state auto insurance laws, involving a product that is more affordable and available than health insurance, suggest a threshold degree of difficulty" with individual mandate).

126. See Holahan \& Blumberg, supra note 4, at w437, w441 (noting inverse correlation and "attractiveness of Connector plans to small employers relative to plans in the non-Connector market").

127. See Deborah Solomon \& David Wessel, Health-Insurance Gap Surges as Political Issue, WALL ST. J., Jan. 19, 2007, at Al (stating the breakdown of how people in the U.S. got their health insurance in 2005; 80 million have government insurance and 46 million are unsinsured).

128. Christopher Hogan et al., Tracking Health Care Costs: Inflation Returns, 19 HEALTH AFF. 217, 219-20 (2000), available at http://content.healthaffairs.org/cgi/reprint/19/6/217.

129. Melden, supra note 119, at 410; see also LISA CLEMONS-COPE \& BOWEN GARRETT, THE

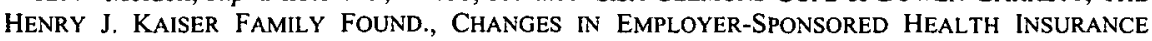


2005 , the number of employers offering health insurance had fallen from 69 to $60 \%$ since $2000 .^{130}$ Rising premiums also impact employee take-up rates.

The upshot is that even with the employer mandate, the Massachusetts Plan does not address the underlying problem of rising health care costs and insurance premiums. Instead, it merely reallocates the incentives for coverage. If employers respond favorably by maintaining or expanding employee health plans, the individual insurance market will shrink, making individuals' ability to purchase "affordable" individual coverage through the Connector increasingly difficult.

\section{Risk Segmentation: The Insurance "Death Spiral"}

Another problem with the Connector is risk segmentation Relatively low-risk customers will be drawn to the low-premium HDHPs, leaving higher risk customers and comprehensive plan purchasers facing increasingly, perhaps prohibitively, higher premiums. HDHPs tend to appeal to young, healthy people who do not anticipate using health care services. As relatively healthy people enroll in HDHPs, sicker patients continue to adversely select more comprehensive plans, which increasingly become more expensive because they cover only the "bad" risks. Higher utilization of comprehensive plan services means insurers will increase premiums to cover the higher costs, making those plans less affordable for people who need or choose them. As lowrisk customers move to HDHPs and high-risk customers move to comprehensive plans, the risk pooling effects of the Connector are compromised. In addition, lower demand for comprehensive plans means lower availability and less competition, driving prices up even higher. Customers requiring comprehensive care fall out of coverage as they can no longer afford premiums and again become uninsured. Hence, the "insurance death spiral" results. ${ }^{131}$

SPONSORSHIP, ELIGIBILITY, AND PARTICIPATION: 2001 TO 2005 (2007), available at http://www. kff.org/uninsured/upload/7599.pdf (describing health insurance industry trends from 2001 to 2005); FRONSTIN \& COLLINS, supra note 123, at 6-7, 13 (reporting health care costs under various types of plans).

130. Kaiser Comm'N ON Medicaid \& The Uninsured, The Henry J. Kaiser family Found., Who ARE the Uninsured? A Consistent Profile ACross National Surveys 5 (2006), available at http://www.kff.org/uninsured/upload/7553.pdf; Larson \& Dettman, supra note 122 , at 1095 (citing same).

131. See Wendy K. Mariner, Can Consumer-Choice Plans Satisfy Patients?, 69 BrooK. L. REV. 485, 511 (2004) (noting that consumer-choice health plans can encourage risk-pool fragmentation and initiate an "insurance death spiral" as "healthier people enroll in consumer-choice plans," while 
Whether the insurance death spiral will result in Massachusetts depends in large part on where the affordability scale is set. Setting it low would bring more people into the Connector risk pool because it would be easier to comply with the individual mandate, resulting in better loss spreading among individuals. Setting it high would mean more people qualifying for government subsidies through CCHIP, shifting the health insurance cost burden back to the government.

\section{Name-Only Coverage and Consumer Bankruptcy}

Consumers buying HDHPs face a risk of catastrophic health care costs similar to people who have no insurance at all. Suppose a young, risk-taking individual, who is just starting his career, has a serious car wreck, or gets a terrible diagnosis. He may have paid $\$ 60$ per month under a low-premium Connector plan to comply with the individual mandate. But now he must spend $\$ 3000$ (or $\$ 10,000$ for a family) upfront to meet the plan deductible before insurance coverage kicks innot to mention substantial copays at every turn of treatment. ${ }^{132}$ Even for routine care, patients must pay the first $\$ 3000$ of check-ups, prescription drugs, and laboratory tests before any insurance coverage is available. Most individuals and families do not have that level of savings. Indeed, if they were cautious enough to maintain substantial savings, they would likely have purchased comprehensive plans from the outset. The financial exposure of enrollees in HDHPs is a serious drawback to relying on those types of products to achieve universal coverage. The "coverage" obtained may be no more than nominal. Medical debt is one of the most important contributors to consumer bankruptcy in the United States. ${ }^{133}$

HDHPs may also have hidden or surprise coverage exclusions, such as an annual limit on the number of physician appointments or exclusions for prescription drugs, maternity, and other common services.

sicker individuals enroll in competing plans).

132. See NiCHOLS, supra note 40 , at 2 (noting that while state law requires maternity coverage, "it is also technically permissible to satisfy the insurance purchase requirement with a $\$ 10,000$ family deductible policy").

133. See David Himmelstein et al., Illness and Injury as Contributors to Bankruptcy, 2005 HEALTH AFF.: WEB EXCLUSIVES w5-63, w5-70, available at http://content.healthaffairs.org/ cgi/reprint/hlthaff.w5.63vl.pdf (stating that "medical problems contribute to about half of all bankruptcies"); Melden, supra note 119, at 411-12, n.36 (citing sources); see also Melissa B. Jacoby, Individual Health Insurance Mandates and Financial Distress: A Few Note from the Debtor-Creditor Research and Debates, 55 U. KAN. L. REV. 1247 (2007). Cf. Stephen J. Ware, "Medical-Related Financial Distress" and Health Care Finance: A Reply to Professor Melissa Jacoby, 55 U. KAN. L. REV. 1259 (2007). 
Massachusetts's mandatory coverage laws protect somewhat against bare-bones policies, but the mandatory coverage requirements also drive up costs, making it harder for other types of plans to compete. Under Governor Romney's proposal to exempt Connector plans from existing and new mandatory coverage, insurers could have offered individually tailored, a la carte plans. But that approach would radically alter a fundamental feature of the Massachusetts insurance market. Exempting Connector plans from mandatory coverage requirements would disrupt the intended cost-spreading approach that ensures that coverage for certain essential services such as maternity and mental health remains affordable. ${ }^{134}$

\section{Poor Health Outcomes}

Another problem with HDHPs is that patients may avoid preventative or necessary medical care to avoid paying the upfront outof-pocket costs. High deductibles and copayments are intended to serve as a moral hazard "check" on over-utilization and a mechanism for patients to internalize the cost of care. But there is a substantial risk that the check will work too well. People may forego preventative care, fail to follow up with referrals to specialists or diagnostic testing, or decide not to have prescriptions filled, exacerbating health conditions. ${ }^{135}$

In addition, patients may be unable to distinguish between medically necessary and merely "discretionary" medical care. That concern is not specific to the Connector but can be alleged generally against consumerdriven health care (CDHC). $\mathrm{CDHC}$ operates on the presumption that individuals can negotiate, select, and bargain effectively for health care. ${ }^{136}$ There are reams of literature on imperfections in health care

134. See Metro. Life Ins. Co. v. Massachusetts, 471 U.S. 724, 731 (1985) (describing background of Massachusetts mandatory mental health coverage law).

The legislature believed that the public interest required that it correct the insurance market in the Commonwealth by mandating minimum-coverage levels, effectively forcing the good-risk individuals to become part of the risk pool, and enabling insurers to price the insurance at an average market rather than a market retracted due to adverse selection.

Id.

135. See FRONSTIN \& COLLINS, supra note 123, at 15-19 (reporting statistics on consumers who skipped treatment or prescriptions); Mariner, supra note 131, at 510 ("[I]f people forego needed care because of cost, their problems may simply be delayed or exacerbated, affecting their lives and possibly requiring more expensive care in the future."); Melden, supra note 119, at 416 (describing cost-related access to care problems with high-deductible plan enrollees).

136. See Melden, supra note 119, at 414-17 (discussing the "myth of discretionary health care spending"). 
markets that seriously impair consumers from shopping for medical care like any other consumer good or service. ${ }^{137}$ Perversely, one of the drivers behind the managed care trend was over-utilization by providers under cost-reimbursement models of health insurance. Capitation and other fixed payment strategies and managerial oversight were designed to check providers' moral hazard to order or provide more care to insured patients than they otherwise would. If managed care did not trust medical providers to make sound professional judgments about medical necessity, it is difficult to accept CDHC's suggestion that patients, as lay people, will be able to prudently make those same types of determinations.

This subpart identified potential problems with the Connector's goal of bringing affordable health insurance to individuals and small groups. Individuals will likely continue to opt out of health insurance coverage, despite the mandate. Moreover, the risk-pooling advantages of the Connector seems to work against the employer incentives to the extent that the more workers who are insured by employer group plans, the fewer individuals left purchasing through the Connector. In addition, adverse selection of low-risk consumers into HDHPs and high-risk consumers into comprehensive plans would further skew the costspreading effect. ${ }^{138}$ HDHPs also carry certain health and consumer credit risks for individuals who decide to meet the new individual mandate by purchasing those plans. Given these vulnerabilities, it seems unlikely that the Connector will operate effectively to facilitate individual health insurance purchases without government interference. Additional government regulation and subsidization will likely be demanded if

137. See, e.g., Deborah Haas-Wilson, Arrow and the Information Market Failure in Health Care: The Changing Content and Sources of Health Care Information, 26 J. HEALTH POL. POL'Y \& L. 1031 (2001) reprinted in UNCERTAIN TIMES: KENNETH ARROW AND THE CHANGING ECONOMICS OF HEALTH CARE 170-71 (Peter J. Hammer et al., eds. 2003) (describing Arrow's analysis of problems in medical markets); Kenneth J. Arrow, Uncertainty and the Welfare Economics of Medical Care, 53 AM. ECON. REV. 941, 951 (1963) ("Because medical knowledge is so complicated, the information possessed by the physician as to the consequences and possibilities of treatment is necessarily very much greater than that of the patient...."); see also JOSEPH P. NEWHOUSE, PRICING THE PRICEless: A Health CARe Conundrum 83 (2002) ("Many economists, however, and virtually all non-economists start from the presumption that consumer or patient information is poor.'); John V. Jacobi, After Managed Care: Gray Boxes, Tiers and Consumerism, 47 ST. LoUIS U. L.J. 397, 399-400 (2003) (discussing problems of the health care market); Uwe E. Reinhardt, The Pricing of U.S. Hospital Services: Chaos Behind a Veil of Secrecy, 25 HEALTH AFF. 57 (2006) (discussing pricing and payment problems of the health care market); Thomas Rice, Can Markets Give Us the Health System We Want?, 22 J. HEALTH POL. POL'Y \& L. 383, 415-18 (1997) (discussing problems of the health care market).

138. See Mariner, supra note 131, at 511 (observing same effect); Melden, supra note 119, at 421 (same). 
Massachusetts's goal of universal coverage is to be achieved or approached.

\section{Expected Regulatory Responses}

The classic response to failure of competitive markets is increased government regulation and subsidization to help the market to function as it should. ${ }^{139}$ The Connector will likely be no different. ${ }^{140}$ Some of the expected interventions may have a salutary effect while others may worsen the existing market imperfections.

First, there will be an increased need for CCHIP or other government subsidies to individuals as plans become less "affordable." The need for subsidization is directly tied to the affordability scale, which has not yet been set. If affordability is set low, more individuals may comply with the mandate. If it is set high, fewer individuals will be able or willing to comply without government subsidies. Massachusetts might also consider special subsidies for "medically needy" individuals who require comprehensive plans, rather than HDHP plans, which are more appropriate for relatively healthy individuals. These special subsidies could prevent or slow the insurance death spiral that could eventually price medically needy people out of coverage.

Although Massachusetts requires mandatory coverage of certain types of medical treatment, there is no standardized benefit package under the Connector. This variation exposes consumers to surprise exclusions and limits on services, which may result in name-only coverage. In addition, lack of standardization makes it difficult for consumers to shop and compare plans. Therefore, the State might consider requiring a standard benefits package for plans certified though the Connector.

To address the adverse health and consumer credit concerns with HDHPs, lawmakers might consider implementing "first-dollar"

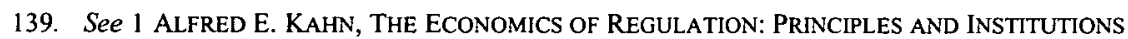
17 (1970) ("[T]he single most widely accepted rule for the governance of the regulated industries is regulate them in such a way as to produce the same results as would be produced by effective competition, if it were feasible."). See generally STEPHEN BREYER, REGULATION AND ITS REFORM 15-35 (1982) (discussing various traditional rationales for regulation).

140. See Melden, supra note 119, at 423-26 (describing "regulatory vacuum" over HDHPs); Miller, supra note 38, at w451 (suggesting that the "political temptation ahead will be to change the role of the Connector from a neutral clearinghouse into a more aggressive regulator and monopsony purchaser"); Universal Health Insurance in a Private Market? Don't Bet on It, WALL ST. J., Jan. 26, 2007, at B6 (offering letters responding to David Henderson's Terminatorcare article, supra note 91, which rejected the view that health insurance coverage is best achieved through deregulation, rather than increased regulation). 
exemptions for preventative care, diagnostic testing, and prescription drugs. ${ }^{141}$ Those expenditures would be covered notwithstanding the plans' otherwise high deductibles. Accordingly, patients would not be put to the hard choice of whether to pay expensive out-of-pocket costs or forego early intervention, preventative, or necessary medical care. Premium limits on comprehensive plans would also help address affordability concerns. Similarly, to address the risk of medical bankruptcy posed by HDHPs, lawmakers could restrict the level of deductibles and copayments. ${ }^{142}$

Rate controls, or price caps, are always controversial for competitive market proponents. ${ }^{143}$ Nevertheless, insurance rate controls, as suggested above, and caps on provider charges or reimbursement might be necessary to address the root problem in health care: exorbitant costs. ${ }^{144}$ In the current market, pricing of medical services is largely left to providers, responding to market and other incentives to increase rates. Managed care and other insurance contracts have restricted or fixed provider reimbursement through certain bargained-for arrangements. In addition, government health care programs typically offer fixed reimbursement, based on fee schedules or predetermined payment amounts. The Massachusetts Plan fails to address rising health care costs in any respect. In fact, the one provision related to provider reimbursement works in the opposite direction, increasing Medicaid reimbursement by $\$ 540$ million. ${ }^{145}$ Ultimately, containing rising health

141. First-dollar exemptions are not required for federal tax benefits of HSA-HDHPs, although states could provide exemptions for state taxes. See Melden, supra note 119, at $406 \mathrm{nn} .12-13$ (citing 26 U.S.C. $\S 223(\mathrm{c})(2)(\mathrm{C})$ ) and Internal Revenue Bulletin 2004-15).

142. See id. at 429-31 (proposing same).

143. See BREYER, supra note 139, at 36-59 (discussing ratemaking); KAHN, supra note 139, at 159-81 (same); RICHARD A. POSNER, ECONOMIC ANALYSIS OF LAW 8-10 (6th ed. 2003) (depicting and describing inefficiency of price controls); id. at 383-87 (describing problems with regulating firms' profits).

144. See, e.g., STATE HEALTH WATCH, supra note 11 (noting that Massachusetts plan does not address the "cost-effectiveness gap in American health care, marked by spending more than any other country but not having the best health outcomes"); Steffie Woolhandler et al., Costs of Health Care Administration in the United States and Canada, 349 NEw ENG. J. MED. 768, 768 (2003) (concluding that U.S. health care administrative costs totaled $\$ 1059$ per capita, compared to $\$ 307$ per capita in Canada); Bernasek, supra note 11 (comparing United States and other countries' health care spending); David Gratzer, Where Would You Rather Be Sick?, WaLL ST. J., June 15, 2004, at A14 (comparing health care spending and health outcomes in United States and Canada); David Leonhardt, $A$ Lesson from Europe on Health Care, N.Y. TiMES, Oct. 18, 2006, at C1 (comparing health care in the United States with that of Europe and Canada).

145. See McDonough et al., supra note 12, at w426 (noting $\$ 90$ million increase in Medicaid reimbursement over three years, or $\$ 540$ million total); Tumbull, supra note 12 , at w455 (noting sizeable Medicaid rate increases). 
care costs, rather than expanding health insurance coverage, may be the key to the success of Massachusetts's and other health reform efforts. ${ }^{146}$

\section{CONCLUSION}

Massachusetts's Health Care Reform Plan was a groundbreaking effort and the first in a recent trend of state-directed health care reform. Other states have followed the Massachusetts lead and federal lawmakers are considering ways to coordinate national reform efforts with state experiments. Therefore, the key elements of Massachusetts's patchwork plan to close the existing gaps in health insurance coverage merit careful consideration. In particular, this Article examines the Connector, a riskpooling mechanism through which Massachusetts's regulators hope to facilitate individuals' compliance with the new state mandatory health insurance law. Several expected features and vulnerabilities of health coverage offered through the Connector plans may impair the Plan's success. Therefore, we can anticipate that Massachusetts's still-to-come "fifth wave" of health care reform will almost certainly focus on the issue of cost-containment in medical services. Until that root problem of health care disparities and lack of access is addressed, other reforms promise to narrow but not close the gaps.

146. See Tumbull, supra note 12, at w455 ("The long-term success and sustainability of the new law will depend on finding successful ways to contain health care costs."). 